\title{
Effective dispute settlement as a mechanism of economic attractiveness
}

\author{
Larisa Zaitseva ${ }^{1, *}$ \\ ${ }^{1} 10^{\text {th }}$ State Arbitration Appellate Court, 117997, Sadovnicheskaya str., 68/70, Moscow, Russia
}

\begin{abstract}
Commercial disputes the number of which is growing every year can cause economic imbalance if a country doesn't obtain ADR (Alternative disputes resolution) technologies and methods implementation experience. In the Russian Federation separate branch of courts - state arbitration courts - is established and it demonstrates high quality of litigation. But effective functioning of judiciary (its accessibility, low costs and rapid procedures) doesn't signify universal character of litigation, especially in the field of investment and construction projects dealing with socially significant objects such as apartment complexes or infrastructure facilities. Within one project different controversies and misunderstandings can arise which should be resolved without delays, abuse of rights and termination of collaboration. The article is focused on three main aspects, defining approaches to ADR promotion: features of legal and judicial system of a concrete state, availability of elaborate measures ensuring ADR successful development, specifics of practice area. Certain means and technologies of $\mathrm{ADR}$ are proposed in order to eliminate infringement of construction process participants' rights. Analysis of state arbitration courts statistics has shown a very low level of ADR implementation. Legislative and explanatory measures fail to cope with this problem. In this connection concrete organizational and educational measures are suggested to enhance the process of ADR promotion for ensuring economic attractiveness.
\end{abstract}

\section{Introduction}

Sustainable development of each state especially in its economic dimension causes the necessity of ADR methods introduction and further implementation due to their flexibility, constructive character and ability to long-term collaboration support. Scientific and practical approach toward ADR is determined by certain essential aspects, among them are: features of legal and judicial system of a concrete state, availability of elaborate measures ensuring ADR successful development, specifics of practice area (construction, employment, family law etc.).

The first aspect refers to such important issues as terns of state courts procedures, legal costs, judges' qualification and priorities of judicial development. Taking into consideration foreign countries experience in particular unpredictable, cumbersome and expensive

\footnotetext{
* Corresponding author: avanzar@list.ru
} 
litigation that served as an incentive for ADR usage, in the Russian Federation we observe different preconditions: rapid litigation, low-cost procedures in state courts and the lack of ADR professional skill.

The second aspect implies legislative, educational, practical and organizational measures which help to promote the idea of ADR in the society and make people get used to compromise and friendly cooperation.

The third aspect is focused on certain areas within which disputes arise. Some of them are characterized by plurality of participants, complexity of issues, large scope of contracts and participation of public officials. Global engineering and construction are bright examples of such areas.

\section{Materials and methods}

ADR presumes a wide range of methods and technologies which are cost-cutting and help to avoid a full-blown trial. Such methods are in great demand in construction sphere, since within one project plural contracts and obligations can exist which give rise to different discrepancies. Time consuming litigation is the riskiest way to sort out controversies because it leads to project realization delays, share holders' rights infringement and growing tension among participants.

Legislative measures aimed at ADR promotion in the Russian Federation took place in 2010 through the adoption of Basic legal act regulating the ADR sphere, in 2014 the Supreme Arbitration Court of the Russian Federation issued interpretation and review focused on ADR problems $[1,2]$.

One of the main purposes of these measures was caseload reduction. In order to fulfill ADR concept some judicial districts make attempts of its promotion through conferences and workshops. Besides certain important steps were initiated by Chamber of Commerce and Industry of the Russian Federation to ensure cooperation with courts and public officials aimed at ADR usage.

Specific regional organizations providing ADR services were also established in order to settle a wide range of disputes. Still these organizations don't have specialization and experts dealing with disputes aren't focused on economic issues. The only exception is non state arbitration institutions, especially International Commercial Arbitration Court that functions within Chamber of Commerce and Industry of the Russian Federation.

Speaking about commercial arbitration it's important to mention the ongoing reform of this sphere aimed at improving of disputes settlement services and increasing the credibility of non-state arbitration institutions. Additional requirements for their composition, qualification and minimum quantity of arbitrators have been introduced. Results of this reform are ambiguous: from 1400 arbitration institutions only 4 major non state courts and centers are functioning as of March 2018 [6].

\section{Results}

Legislative measures and initiatives in the Russian Federation do not meet the needs of modern economic environment and are incapable of forming sound business climate. Above mentioned steps, including adoption of basic legal act regulating ADR and just few reviews of the judicial body haven't changed the attitude to ADR. State arbitration courts statistics show insignificant percentage of disputes resolved by mediators or other third parties and most disputes in construction sphere end in binding judicial decision but not in compromise [4]. 
On the one hand we observe the system of state arbitration courts which functions effectively and constantly improves the quality of litigation. On the other hand state courts should not deal with the whole load of disputes especially in case of violations of both parties. The only possible solution isn't reduced to increasing the number of judges or introducing pretrial binding procedures (though this method has demonstrated its potential in practice). Promotion of ADR in such a specific sphere as construction is able to cope with essential goals existing nowadays. International Commercial Arbitration is undoubtedly an effective and modern means of ADR that is represented in the Russian Federation. But it is not sufficient for the whole spectrum of legal relations and areas of cooperation.

The perspective of ADR development is connected with the functioning of non-state arbitration institutions and different associations possessing specific experience in dealing with all sorts of disputes. In order to see how such organizations should operate let's take the example of JAMS (Judicial Arbitration and Mediation Services). Essential advantage of this worldwide organization is availability of practices in different fields, which need particular approaches (family law, employment, class action, health care etc.). JAMS Global Engineering and Construction Group ("GEC") provides expert mediation, arbitration, appellate arbitration, project neutral, Dispute Review Boards, Interim Adjudication, Surety Bond Adjudication to the U. S. and global construction industry. It offers a wide range of dispute resolution clauses to eliminate contractual obstacles of effective settlement and drafts International Mediation and Arbitration Rules [11].

Practical experience of ADR specialized organizations has shown that specialization of experts, neutrals and mediators is relevant for successful settlement. Qualification of third parties and methods of handling disputes differ for example in construction sphere and family law: the first case requires engineering and technological competence while the second more skills of psychologist.

Another important issue of ADR promotion refers to educational and scientific sphere. As mentioned above ADR services need special professional skill which should be obtained firstly on educational level through post graduate or masters programs and secondly by practicing and taking part in seminars and workshops. If we take for example The Arbitration Center at The Russian Union of Industrialists and Entrepreneurs (RSPP) key third parties who take part in ADR received training in The Chartered Institute of Arbitrators (CIArb) [7]. Also such organizations as The League of mediators organizes special trainings and initiated implementation of conflicts management program at the Faculty of Philosophy of St. Petersburg State University [8].

\section{Discussion}

Turning back to essential aspects of ADR promotion it is necessary to underline practical and conceptual problems and pitfalls.

As far as priorities of judicial development are concerned no blueprint of ADR development exists nowadays. Only fragmentary attempts are being made to introduce ADR practices for example the creation of mediation rooms in state courts or reference in state courts' decisions to the possibility of ending disputes by settlement agreement or using mediation.

In this context it is necessary to mention the advantages of ADR in such socially significant areas as investment and construction activity: the opportunity to involve public officials in dispute settlement process, especially those who give permissions and approve documentation. Nowadays many disputes initiated by developers deal with illegitimate decisions and rulings of public bodies which can result in breach of terms and considerable penalties [3]. Still such improper actions don't cause any consequences or liability of public authorities. 
As mentioned above only non-state commercial arbitration practices are being developed nowadays. Still such procedures aren't adequate for all types of disputes as it needs special proceedings for choice of arbitrators and their assignment, long term of proceedings and decision making, long-lasting hearings and considerable term of decision preparation (in practice it can amount to 6 months in complicated disputes). We also shouldn't forget about the cost of the procedure - it is minimum five times more expensive than state court trials. Thus arbitration remains an elite means of ADR, that is necessary in large-scale disputes.

Furthermore it is important to highlight the lack of cooperation between state arbitration courts and non-state ADR institutions. Exchange of experience would be very useful because general approaches of the latter are less formal and more compromise oriented.

Another important issue is state courts' negative attitude to arbitration institutions and restriction on their competence. Such tendencies have been frequently underlined by researches in respect of The Supreme Arbitration Court of the Russian Federation [5].

At the same time construction sphere needs flexible and project-oriented methods such as Project Neutrals, Dispute Review Boards, Interim Adjudication. Experts involved in projects realization supervise them from the initial stage and prevent controversies or resolve them promptly. Special organizations can provide construction companies with cost-effective and efficient managers who will deal with discrepancies arising from contractual obligations. Groups of experts enable parties to a contract to cover all possible issues: legal, technical, ecological, designing etc. [11]. All expenses connected with the use of specific ADR methods should be taken into consideration by incorporating clauses in contracts. As a rule such expenses are divided among parties of a contract [14].

Promotion of above mentioned methods and procedures will be possible under the condition of simplified mechanisms of review and decisions enforcement with the participation of state courts. These procedures shouldn't delay the process of construction otherwise ADR will forfeit its main advantage - time saving [15].

As far as the second aspect is concerned educational measures are of extreme importance for the creation of effective system of ADR. Nowadays we face the absence of authoritative programs of ADR research in Russian universities and scientific centers (only few courses at legal faculties). Even ex-judges don't posses specific skill of dispute settlement based on compromise and future friendly cooperation. Only special training and promotion of programs at universities can contribute to the formation of professional environment.

The second step aimed at ADR promotion is creation of specific organizations providing services of dispute settlement in different spheres of collaboration. The example of such organization in the Russian Federation is «South-Expert» engineering company [9]. This measure can solve the problem of lengthy search of experts in the field of investment and construction.

As it is demonstrated in statistics of state courts social significance of certain legal relations isn't sometimes taken into account due to huge caseload and lack of specific knowledge and specialization. That's why separate institutions focusing on economic disputes settlement problems are really relevant nowadays.

\section{Conclusion}

The ADR potential hasn't been revealed yet. Even effective and rapid litigation cannot serve as an adequate way for all types of disputes since some of them need ADR due to complexity of raised issues and problems. All efforts made in the Russian Federation are aimed at the improvement of state courts system (for example, the increase in the number of judges in state arbitration courts) but the way out of complex situation lies in the scope of ADR development. 


\section{References}

1. Federal Act of the Russian Federation (27.07.2010) № 193 «About alternative disputes resolution procedure with the participation of mediators (procedure of mediation)», 168 (2010).

2. The Plenum Resolution of the Supreme Arbitration Court of the Russian Federation (18.07.2014) № 50 «About conciliation of parties in arbitration procedure», 28, (2014).

3. The materials of arbitration case № A41-6992/2017 (http://kad.arbitr.ru)

4. Summary statistics on the activities of the courts for 2015, 2016 (http://www.cdep.ru /index.php?id=79)

5. N. G. Doronina, N. G. Semilyutina, M. A. Tsirina, Newsletter of the ICAC at the Chamber of Commerce and Industry, 14, 1, 25-58 (2017)

6. E. Efimenko, Arbitration courts after the reform: normal flight (https://pravo.ru /story/201264/)

7. Arbitration center at the Russian Union of Industrialists and Entrepreneurs: General Information (https://arbitration-rspp.ru/about/information/)

8. Training of mediators at St. Petersburg State University (http://arbimed.ru/obucheniei-povyshenie-kvalifikacii)

9. The Engineering company South-Expert (http://ugexpert.ru/)

10. M. Y. Veselovsky, M. A. Izmailova, A. V. Bogoviz, S. V. Lobova, A. N. Alekseev, Quality - Access to Success, 19(162), 60-66 (2018)

11. Dispute Review Board (http://www.elliotts.com.au/drb.html)

12. M. Y. Veselovsky, M. A. Izmailova, A. V. Bogoviz, S. V. Lobova, Y. V. Ragulina, Quality - Access to Success, 19(163), 30-36 (2018)

13. Global Engineering and Construction Dispute Resolution (https://www.jamsadr.com /construction)

14. E. Taş, Ö. Fırtına, ITU J Faculty Arch, 12(2), 187-204 (2015)

15. M. Latham, Industry Review of Procurement and Contractual Arrangements in the UK Construction Industry (HMSO Publications Centre, 1994) 